\title{
Local level E-government in international comparison
}

\author{
Prof. Dr. Bernd W. Wirtz \\ German University of Administrative Sciences Speyer \\ Freiherr-vom-Stein-Straße 2, Speyer 67346, Germany \\ Tel: +496232 654323 E-mail: wirtz@uni-speyer.de
}

Phillip Nitzsche (corresponding author)

German University of Administrative Sciences Speyer

Freiherr-vom-Stein-Straße 2, Speyer 67346, Germany

Tel: +496232654323Ｅ-mail: p.nitzsche@gmail.com

Received: June 25, 2013 Accepted: July 12, $2013 \quad$ DOI: 10.5296/jpag.v3i3.3907

\begin{abstract}
In recent years the importance of E-government has, both in literature and in practice, steadily increased. In particular, the use of local E-government has attracted more and more interest and attention. Local E-government portals are often the first point of contact between the citizen and the E-government, providing a wide range of services. In international comparison, however, significant differences can be observed in terms of the extent and level of development of E-government services. This article, therefore, examines the breadth and depth of local E-government services based on a comparative case study and highlights recent trends. The cases represent the world's leading E-government portals of the cities or city-states of New York, Hong Kong and Singapore. It turns out that there exists a significant implementation gap both between the different case studies but also in the different categories of municipal services. In addition, the growing importance of Web 2.0 services in E-government is confirmed and illustrated by the three portals considered in this study.
\end{abstract}

Keywords: local E-government; E-Government portals; service innovation 


\section{Introduction}

The dynamic development of modern information and communication technologies in recent years has led to the widespread use of E-government at all levels but especially at the municipal level. Despite this substantial increase in importance there is not yet a common understanding of the concept of E-government. Contrary to the originally rather narrow understanding of E-government in the literature, today nearly every area in which the government is substantially and actively influenced and shaped by developments in the fields of information technology and communication technology is subsumed under the concept of E-government, such as e-Health.

However, E-government has special relevance not only for the state and the administration but also for citizens and businesses. Customers-cum-citizens would like to see a more flexible and transparent administration and a more comprehensive range of services on the web. In most case the municipal E-government represents the first electronic contact point and is often the most important on-line interface between citizens and administration. As such, it can contribute considerably to the acceptance the E-government. Hence, the central importance of local portals can be seen. However, by which criteria we can identify a good local E-government solution and which services should be integrated into such a solution.

A decisive factor in the evaluation of e-government is the level of development of E-services offered. Numerous studies have shown that the implementation of E-government services in most municipalities does not progress as predicted. In addition, significant differences in implementation can be observed at both the national and international levels. While the vast majority of municipalities still have a relatively low level of E-service provision, a few municipalities already possess very advanced applications. The aim of this paper is to provide an insight into the development of innovative E-government services through the analysis of these internationally outstanding cases. For this purpose, three leading municipal E-government portals were analyzed in terms of their breadth and depth of service and an evaluation of the average service levels was carried out.

To this end, the second section will give an overview of the theoretical context of E-government and develop a classification system for the investigation. The third section will discuss in greater detail the international significance of local E-government and describe the research design. Following this, the fourth section will conduct a comparison of three leading E-government portals using various assessment criteria. The examination of alternatives will begin with a quantitative analysis of service breadth, and then, in a further step, will qualitatively identify the level of E-government development. The aim of the study is to identify the service trends and their implementation at the portals of leading international communities.

\section{E-Government in a Theoretic Context}

Although overall E-government is a rather young field of research, it has steadily gained in popularity, both in the literature as well as in practice. This is partly due to the increased practical relevance of the subject area (Deng, 2008; Lee, 2010). Due to the progressive transformation of public administration into customer-oriented service companies the interest 
of the public sector in modern E-government solutions for the expansion of public services has grown (Al-Sobhi et al., 2011).

\subsection{Research Landscape}

Originally, E-government's primary purpose was to increase the effectiveness and efficiency of all types of transactions in the public sector through the use of modern information and communication technology. The first scientific E-government discussion was thus focused on this area. Since the late 1990s, however, online services have been developed and thus the external perspective has gained in importance for E-government (Roy, 2006). Accordingly, a shift within E-government research occurred, towards a more service oriented view of E-government in which the citizens were increasingly perceived as a "customer" or even "partner" of public administration (Jansen et al., 2010). The private sector, in which the concept of E-business was adopted much earlier, served as the model for both perspectives (Kaisara and Pather, 2011; Irani et al., 2008; Alsaghier et al., 2009).

Consequently, E-government can be divided into an internal perspective, in which the E-government potential as seen by public administration is considered, and an external performance-oriented view in which the citizens become the focus (Grönlund, 2011; Moon, 2002; Al-Haddad et al., 2011). These internal and external perspectives have been even further differentiated in the literature, which has thereby derived four main areas (Moon, 2002): The establishment of a secure intranet and central data processing for networking; the adaptation of E-commerce for the efficient design of transactions; web-based services; and electronic democracy (E-democracy) with the aim of creating greater transparency and democratic legitimacy. In the E-government literature these four core aspects are largely autonomous and self-contained research streams.

There are numerous definitions of E-government, each of which usually emphasizes one of the key aspects of E-government (UNPAN, 2002, Evans, 2005). In addition, definitions have also been established that attempt to unite all the important apects of E-government (Heeks, 2008; Wirtz et al., 2011). A broad definition can be found in the "e-Government Imperative" of the OECD: "The term 'e-government' focuses on the use of new information and communication technologies (ICTs) by governments as applied to the full range of government functions. In particular, the networking potential offered by the Internet and related technologies has the potential to transform the structures and operation of government." (OECD, 2003)

With the increased focus on transactions between citizens and administration to the point of involving the citizens in administrative activities, all the aspects of E-services and E-democracy have received greater attention (Kaisara and Pather, 2011). Here, the emerging phenomenon of Web 2.0 has enriched the scientific debate further and has led to more nuanced views of E-government, views in which citizens have a much more active role (Dawes, 2009; Delitheou and Maraki, 2010). Alongside this, however, discussions regarding the compatibility of E-government with democracy are arising, especially given the digital divide (Khan et al., 2010; Helbig et al., 2009).

In particular, the area of E-Services has developed very dynamically in recent years and 
represents a distinct core area of E-government research (Magoutas and Mentzas, 2010; Arduini et al., 2011). Today, a large part of the scientific work on E-government is addressing E-government services (Wang et al., 2005; Tan and Chou, 2008; Jansen et al., 2010), as does this investigation.

Early on, it became clear that traditional government services could not be transferred to the web easily (Roy, 2006). As a result, numerous works were trying to determine on which particular structures E-services are based. In this context, different theoretical models of E-government (Layne and Lee, 2001; Wescott, 2001; Baum and DiMaio, 2000) have been established. Moreover, the question was raised as to what characterizes E-government services and how they could be evaluated (Wang et al., 2005; Pazalos et al., 2012). In addition to the theoretical models from E-government research, many empirical studies on e-Services have fallen back to using criteria from models in IS research (e.g. TAM, IS-Success) or service research (e.g. SERVQUAL) (Gilbert et al., 2004; Halaris et al., 2007; Chutimaskul et al., 2008; Verdegem and Verleye, 2009; Alanezi et al., 2010).

However, these studies are almost exclusively confirmatory (Thompson et al., 2005; Sung et al., 2009; Chen, 2010; Karunasena and Deng, 2012). Since they deal largely with user acceptance and perceived quality, they do not conduct an examination differentiated by service and thus through which innovative services could be identified. An analysis of trends in the area of E-services should be exploratory in nature. Overall, there are few qualitative exploratory field studies on E-services . As in the confirmatory studies, current exploratory work considers E-services primarily from the perspective of users and thus evaluates the perceived quality of service (Rotchanakitumnuai, 2008). Esteves notes here: "Studies beyond citizens' perspective are less common in the existing eGovernment literature" (Esteves and Joseph, 2008).

Only a few scientific studies attempt to derive the E-service level directly from the services offered. An early approach to evaluation is given by (Kaylor et al., 2001). However, the authors evaluate E-service implementation based on a fixed set of functional dimensions and do not identify any further developments (Kaylor et al., 2001). Later studies in this context also took a similar approach, but are already using E-government stage models for evaluation (Moon, 2002; McHenry and Borisov, 2006). Nevertheless, there are certain functions that were identified in advance, often according to the United Nations E-participation index (e.g. UNPAN, 2008).

In addition, within practitioner reports there are a few descriptive studies that deal with E-services in this way (e.g. Capgemini, 2009). However, these usually have no explicit research design. They have also in common with the above mentioned studies that both the services under consideration as well as their characteristics are defined in advance and, therefore, also do not allow any conclusions to be reached regarding qualitative developments. The qualitative development of E-services and their specific strengths and weaknesses is, however, an important aspect of E-government. "Therefore it is of critical importance to evaluate the e-services developed as part of 'digital city' projects in a way that allows a good understanding of their strengths and weaknesses" (Pazalos et al., 2012). 


\section{Macrothink}

However, it still needs to be said that only a few empirical studies have taken a broad perspective on the topic of E-government services (Pazalos et al., 2012). Most studies are devoted to only certain aspects of a given service and/or focus on specific service types (Wolfinbarger and Gilly, 2003; Halaris et al., 2007; Rowley, 2011; Sumak, 2009). Such a focus, however, limits the discovery of new services, as well as the ability to compare different service categories. In addition, the traditional models of e-service quality grant only limited insights into the implementation of Web 2.0: „Although the impact of customer participation and inter-customer support on service quality is recognised, e service quality conceptualisations and measurement models have failed to incorporate the impact of Web 2.0 on e service delivery" (Sigala, 2009)

In summary, one can state that within the E-government literature there is a lack of qualitative exploratory work that conducts an examination of the development of E-government services on the Web (Wang et al., 2005) from which new trends can be derived. Coursey and Norris make specific mention of this: "Finally, future research should endeavor to get at issues of the maturity and sophistication of e-government offerings (not all services are equal)" (Coursey and Norris, 2008). Therefore, this study addresses the question of what level of development E-government services have reached today and which innovative E-services have emerged in this context.

\subsection{E-Government Concepts}

E-government is a relatively new area of research (Dawes, 2008). Accordingly, the development of theoretical models and basic concepts is not as advanced as in other disciplines, such as regarding E-Business (Norris and Lloyd, 2006). Coursey and Norris identify five theoretical works that propose basic models of E-Government (Coursey and Norris, 2008). Only two of these works have been published in academic journals (Layne and Lee, 2001; Wescott, 2001), with the others having come from more practical fields.

All these works are from the years 2000 and 2001, one came from the perspective of e-government research, from a stages of e-government perspective that in following years was continuously supplemented, while the part on the prototype implementation phase was further developed (United Nations, 2003; Stowers, 2004; Andersen and Henriksen, 2006). Table 1 provides an overview of the five early concepts. 
Table 1. E-Government Models (Coursey and Norris, 2008)Description for above figure.

\begin{tabular}{|c|c|c|c|c|c|c|}
\hline & Step 1 & Step 2 & Step 3 & Step 4 & Step 5 & Step 6 \\
\hline $\begin{array}{l}\text { Baum and Di } \\
\text { Maio }(2000)\end{array}$ & & Presence & Interaction & Transaction & Transformation & \\
\hline $\begin{array}{l}\text { Layne and Lee } \\
\text { (2001) }\end{array}$ & & Catalogue & Transaction & $\begin{array}{l}\text { Vertical } \\
\text { integration }\end{array}$ & $\begin{array}{l}\text { Horizontal } \\
\text { integration }\end{array}$ & \\
\hline $\begin{array}{l}\text { Ronaghan } \\
\text { (2001) }\end{array}$ & $\begin{array}{l}\text { Emerging } \\
\text { presence }\end{array}$ & $\begin{array}{l}\text { Enhanced } \\
\text { presence }\end{array}$ & Interactive & $\begin{array}{l}\text { Transactional } \\
\text { government }\end{array}$ & Seamless & \\
\hline $\begin{array}{l}\text { Hiller and } \\
\text { Bélanger } \\
(2001)\end{array}$ & & $\begin{array}{l}\text { Information } \\
\text { dissemination }\end{array}$ & $\begin{array}{l}\text { Two-way } \\
\text { communication }\end{array}$ & Integration & Transaction & Participation \\
\hline Wescott (2001) & $\begin{array}{l}\text { E-mail and } \\
\text { internal } \\
\text { network }\end{array}$ & $\begin{array}{l}\text { Enable Inter- } \\
\text { organizational } \\
\text { and public } \\
\text { access to } \\
\text { information }\end{array}$ & $\begin{array}{l}\text { Two-way } \\
\text { communication }\end{array}$ & $\begin{array}{l}\text { Exchange of } \\
\text { value }\end{array}$ & $\begin{array}{l}\text { Digital } \\
\text { democracy }\end{array}$ & $\begin{array}{l}\text { Joined-up } \\
\text { government }\end{array}$ \\
\hline
\end{tabular}

All models have in common that they postulate the evolution of E-government from an original rudimentary state to a more advanced form. Thus, all models feature a linear perspective of the E-government development. It is clear that the models are both of a descriptive as well as normative and predictive nature (Coursey and Norris, 2008). In particular, the higher levels of the theories offer an outlook of the possible future evolution of e-government.

Nevertheless there are some points of criticism about these models. At the time of this investigation, there was no empirical evidence relating to the higher levels of E-government development. The criticism in this context has been directed against the foundation of the concepts (Coursey and Norris, 2008). In addition, the practical work has been especially criticized for its assumption that more technology leads to a to higher degree of E-government development. (Reddick, 2004; Andersen and Henriksen, 2006). Further criticism has been directed against the linearity of the approaches (Coursey and Norris, 2008), as in the practical implementation of E-government non-linear processes, such as skipping individual phases, can be observed.

Nevertheless, the basic models became wide spread within the E-government literature. Numerous studies (Moon, 2002; UNPAN, 2008, Capgemini, 2009) have shown that the stage models are appropriate scales for E-government evaluation. In particular, the approach of Hiller and Bélanger from 2001, which is part of a report of the IBM Center for the Business of Government, has proved very practical for this purpose (Hiller and Bélanger, 2001), as the predictions concerning the development of E-Government at the highest levels are largely consistent with the latest developments.

Here, the basic models have been taken directly or adapted to the appropriate context. In the 
current approaches in the literature, one often finds the integration of various stage models, by which they seek to combine the strengths of each approach. Such an approach is also used in this study. It is described in more detail in Section 3.2.

\section{E-government at the local level}

Today, local E-government has increasingly become the centre of attention (Heeks, 2006) in E-Government research. Modern E-government solutions are especially applicable at this level because cities and towns possess many of the policy and decision-making powers of the state sector. The services offered by the local government to citizens and enterprises are extensive and wide-ranging. The transfer of these services stands alongside the development of innovative E-government services as one of the biggest challenges for local E-government.

From the perspective of administration, the initial primary purpose of E-government was to increase efficiency and effectiveness through higher productivity, faster processes, and simultaneous cost reductions. However, creating satisfied "customers" has increasingly become a primary concern of E-government. In the course of this development and the growing possibilities of modern information and communication technologies, the number of available online E-government services has steadily increased. Both the increasing spread of internet connections and new Web 2.0 functionalites are reinforcing this development. Here a transition is taking place from mere information platforms to interactive multimedia platforms. Furthermore, the convergence in communications technology is leading to an ever stronger integration with mobile services (Wirtz, 2010).

These modern communication technologies can be especially effective in local E-government, creating added value for administration and users alike. Local E-government in many places already presents itself as being user-oriented and interactive. Thereby, E-government portals play an increasingly important role at the local level, first and foremost for the citizens and the interests of local businesses. The task of these portals is, inter alia, to provide the citizens on the Internet with a central point of contact and well-structured E-government services.

\subsection{Local E-government in the international comparison}

Numerous past studies have shown that E-government is playing an ever more important role internationally, though the speed of development and trends in different countries vary, in some cases significantly. E-government is therefore evolving differently when considered in international comparison. In the European Union, the differences in implementation of E-government are sometimes striking. The figure 1 below shows, for example, the eighth European Benchmark Measurement developed by Capgemini in cooperation with the European Union (European Commission Directorate General for Information Society and Media, 2009). 


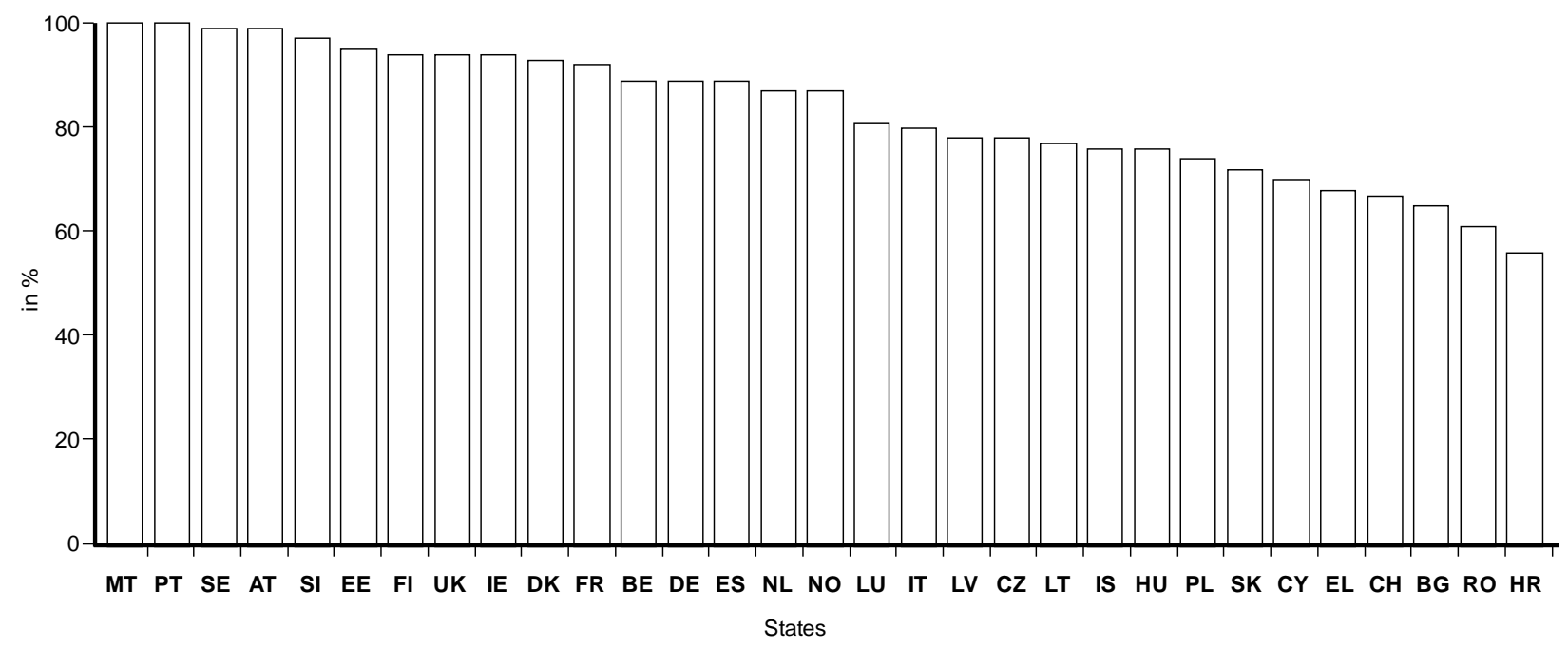

Figure 1: Development of E-government services in the EU

The reasons for the differential inter-state development of E-government, and especially the E-government services, are diverse, ranging from legal, structural or financial barriers to political requirements (Bovaird, 2005; Capgemini, 2009; Eifert, 2004). These findings are also applicable to local E-government. However, in addition, there are also significant national level (intra-state) differences, which are often related to the size of the city or the county (and thus the available product range). Despite the considerable national and international differences in local E-government discovered in comparative international studies, the requirements for E-government portals are very similar (Franzel and Coursey, 2004). The requirements for local E-government portals, such as accessibility, clarity, interactivity, security or service levels, can therefore be regarded as universally valid. Consequently, despite differences in their frameworks, an international comparison of different local contexts is particularly appropriate for this study Thereby, valuable conclusions can be drawn from examining the E-government services implemented by international players in local E-government sectors. In addition, development trends, such as Web 2.0 features, can be identified.

\subsection{Research Design}

The analysis of E-government websites and their service offering is a widely used technique for E-government evaluation. A similar approach is found in Eschenfelder et al. (1997); Smith (2001); and McHenry (2006). Key elements of the studies are always the establishment of the research object, the development of appropriate criteria and the application of these evaluation criteria to the alternatives (e. g. Smith, 2001). This article is also based on such a multi-stage research design. Specifically, the procedure can be divided into four stages: The first step was the identification of leading E-government portals and the selection of the objects of the research. In a second step, appropriate evaluation criteria were established. In order to apply this criteria to the chosen portals, a quantitative analysis was undertaken to create service clusters and evaluate the portals in terms of their range of offerings. On the 


\section{$\triangle$ Macrothink}

basis of these clusters the final evaluation of the portals in terms of their attained level of E-government development is conducted.

Thus, this analysis uses a qualitative multiple case study research design. Yin notes that: "A case study is an empirical inquiry that investigates a contemporary phenomenon within its real-life context, especially when the boundaries between phenomenon and context are not clearly evident (Yin, 2008)." A major advantage of case study research is, therefore, that new and hitherto a priori unknown variables and causal relationships can be discovered (Yin, 2008). Since it is the aim of the study to illustrate the possibilities of all the facets of local E-government portals, a case study oriented approach is particularly appropriate. This method means that in the concrete cases under examination, the service levels of the E-government portals can be discussed without artificial boundaries or pre-conceived hypotheses limiting the process of discovery.

The selection of suitable test cases is of central importance in the case study method. The cases chosen should be those most appropriate for generating deeper understandings and insights into the broader object under examination (Dubois and Araujo, 2007). In this study, three examples from the field of local E-government are used for the identification of general E-government service level. Care was taken to select municipalities of similar size and economic importance in order to ensure comparability. Given the high resource requirements of sophisticated E-government solutions, the selection includes three very large local units which we expect would be able to finance such solutions at a comparable level. To guide the selection process, important E-government rankings like the "Digital Cities Survey" (2010) and the WASEDA University "E-government Ranking" (2010) were used. However, different starting points underlie the three cases. This variation ensures the fullest possible inclusion of the various services provided by local E-government.

Of considerable importance for the analysis is the choice of appropriate evaluation criteria. A broad variety of instruments are available for website evaluation. Especially the research field of E-Business provides a lot of appropriate evaluation criteria such as usability (ease-of-use) and information and content quality (e. g. Ahuja and Webster, 2001; Smith, 2001; Szymanski and Hise, 2001; Chiou, Lin and Peng, 2010). In the context of E-government, the "E-government Maturity Levels" provide a particularly appropriate and well-developed system (e. g. Capgemini, 2009). Here, E-government is investigated with regard to its interaction intensity and is classified accordingly. Of the various approaches that are commonly used in the literature, a classification consisting of five levels of development is appropriate for this investigation (Wirtz, 2010). Figure 2 shows the various stages of development of E-government and examples of the shape they take in a local context. 


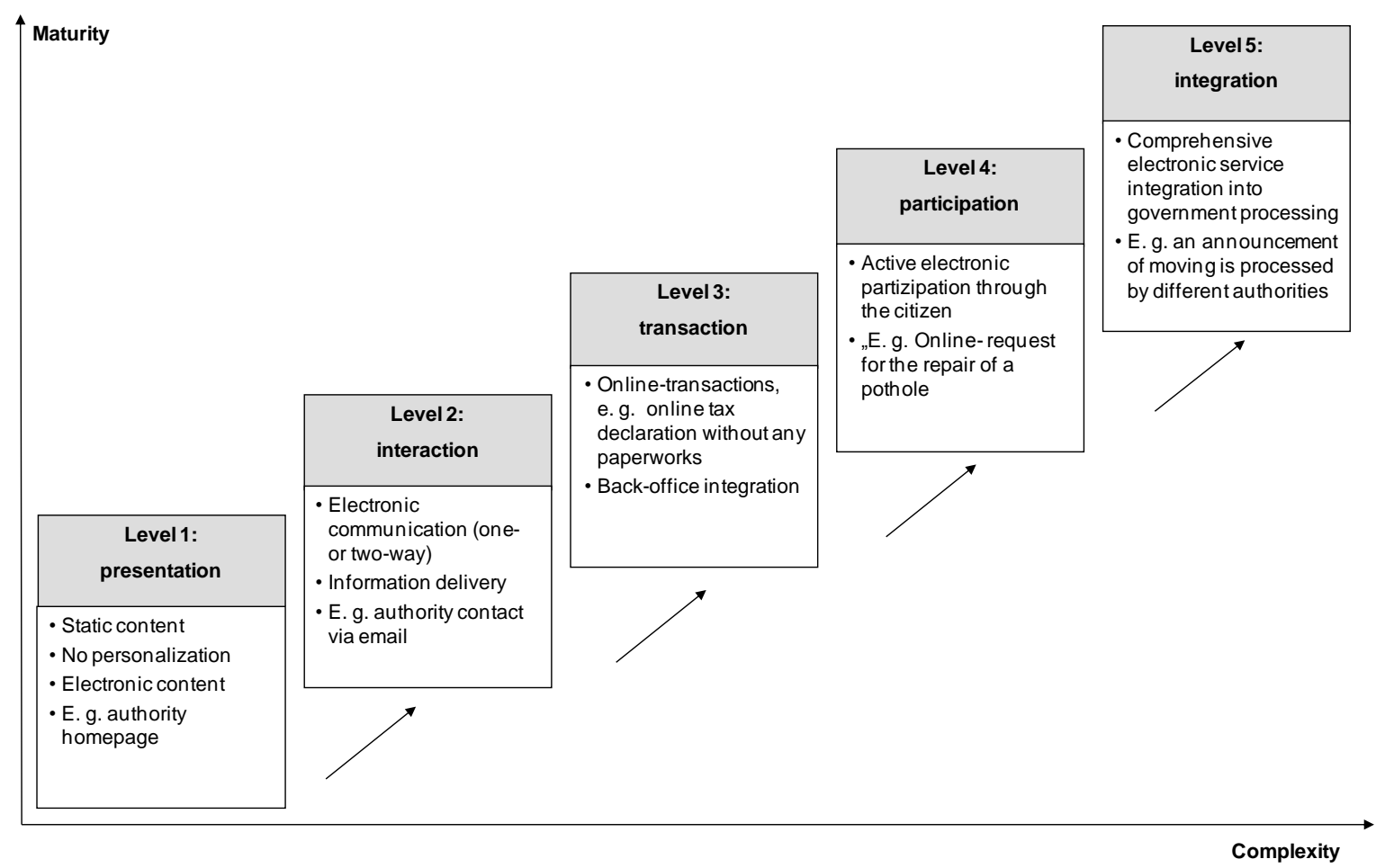

Figure 2: Stages of E-government (Wirtz, 2010)

The development stage with the lowest complexity relating to the interaction is information in electronic. No further interaction takes place. If this basic interaction is augmented by an electronic exchange of data, then E-government is at the stage of communication. At the transaction stage of development, business processes can be initiated and services can be purchased electronically. Going even further is the development level of participation. Here the citizens not only trigger a prefabricated administrative process, but are also actively involved in the design of the administrative procedure. E-government applications at their highest form of interaction can be assigned to the integration stage of development. At this level a comprehensive integration of citizens into E-government processes takes place

The use of the maturity levels for the evaluation of E-government services also raises some difficulties. For each of the five stages, the shape of certain E-government services must be defined, such as occurred in the "Smarter, Faster, Better eGovernment" study prepared on behalf of the European Union. This approach, however, requires a detailed knowledge of the services to be examined. The overall state of E-government services as well as new services and trends can not be identified in this way.

To meet this challenge, the evaluation of the case studies is performed using a simplified variant of the E-government Maturity Levels. According to Capgemini (2009) all E-government services can be divided into "not fully available online" and "fully online" services. A "fully online service" can be spoken of from the E-government level of transaction and upward. One example is an electronic tax declaration. The above levels of participation and integration are also assigned to the category of fully online services, as they 
are extensions of the transaction level. In contrast, information and communication are only partially available online and therefore represent the group of "partial online services".

The actual evaluation was carried out in two stages: First, all the E-government services are counted and clustered. Each single service that attained at least the E-government level of communication (level 2) was considered for the evaluation. Pure information was not included here because of its poor quantification and its limited significance as a separate service for the present analysis. The analysis of the E-government portals and related subportals was carried out, according to Smith (2001), in a manner similar to the hypothetical behaviour of a user: The logical structure of the site was followed via hyperlinks. In a second step, the development progress of the portals in the various clusters was evaluated by means of the developed criteria. For this, the ration of "fully online services" to the overall number of the E-government services was determined and the fully online level of the observations evaluated.

\section{E-government Best Practices in International Comparison}

In the following the selected observations are presented and analyzed. In Section 3.1, the three cities (or city states) - New York, Hong Kong and Singapore - as well as their E-government portals are briefly described and their suitability for the examination outlined. This is followed in Section 3.2 by the analysis of case studies based on the two selected criteria. To illustrate the relevance of the findings of this examination to the development of E-government services, selected services are presented in section 3.4 and are entered into a separate conclusion on modern communication services.

\subsection{E-government portals}

The first case observation, and thus also the starting point of the comparative case study, is E-government in the City of New York. Located in the state of the same name, New York City is, with about 8.3 million inhabitants, the largest city in the United States. The approximately 20 million inhabitants of the overall New York metropolitan area make it one of the most important economic centres in the world and home to the headquarters of many major national and international corporations and organizations, as well as one of the world's most important financial centres. To this, one must add that the City of New York is also an important cultural centre.

This creates special challenges for the local E-government portal of the city. Correspondingly, New York started early with the development of an E-government portal and implemented many services sooner than in other municipalities. Already in 2001 the city began rebuild their pre-existing web presence into the virtual government portal "NYC.Gov" (Accenture, 2001). Its primary objectives were the expansion of service levels through greater interactivity and the integration of new E-government services. The success of these measures has been documented in numerous past studies.

In 2005, New York City finished in second place in the "Digital Governance in Municipalities Worldwide" report, in which 98 large municipalities worldwide were evaluated (Holzer and Kim, 2005). At the same time, the E-government portal of the City of New York satisfied all the drawn upon categories researched in the study. These results were confirmed by the recent 


\section{Macrothink}

Journal of Public Administration and Governance

ISSN 2161-7104

2013, Vol. 3, No. 3

"Digital Cities Survey 2010", which evaluated U.S. municipalities on the basis of a wide range of different assessment criteria, with an emphasis on modern E-government services. Amongst the municipalities with more than 250,000 inhabitants New York City occupied ninth place (Digital Communities Magazine, 2010). Figure 3 shows a section of the E-government Portal NYC.gov.

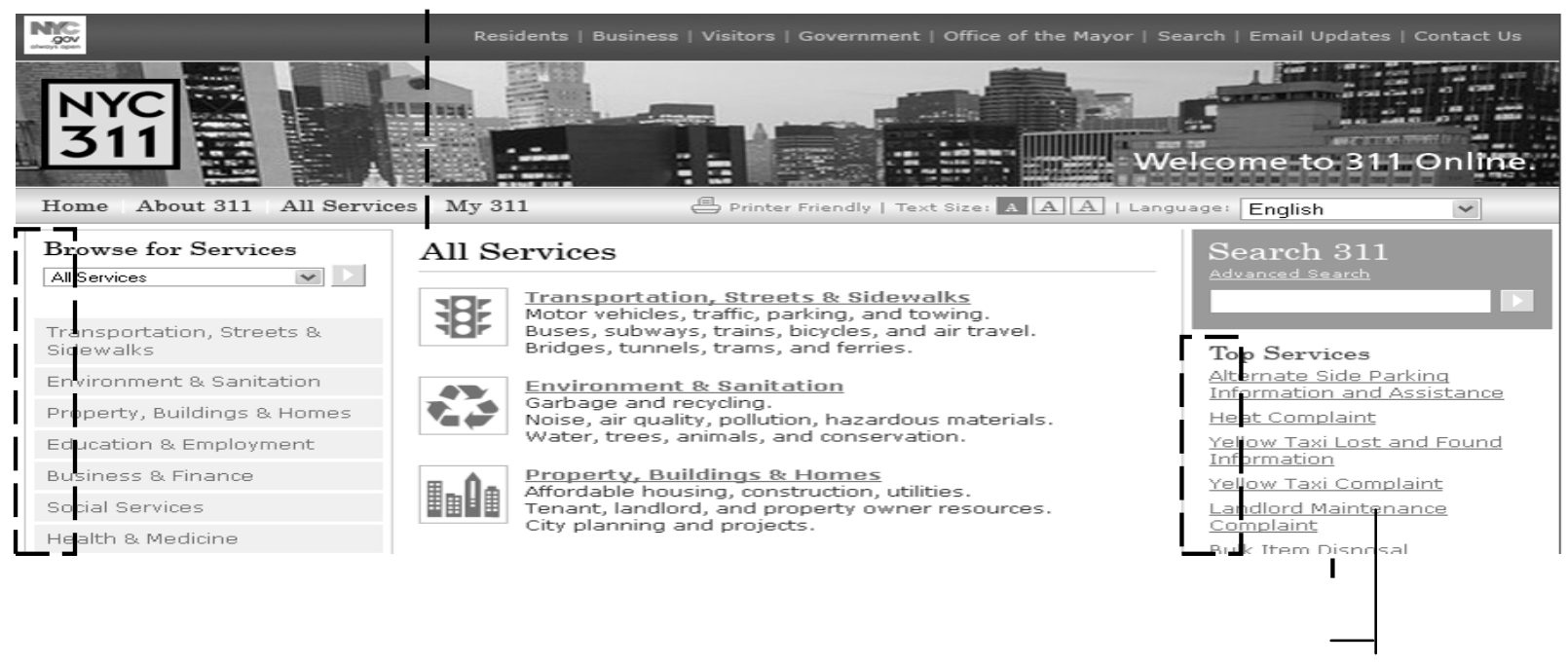

Figure 3: Extract of E-government portal of the City of New York (City of New York 2010b)

The illustrated Subportal NYC 311 combines a variety of E-government services with the public administration's ' 311 ' number and thereby a well-known offline-feature is adeptly integrated into the portal. A user-friendly configuration for the portal was the highest priority. One can also see this claim expressed in one of the mission statements of the portal: "311['s] mission is to provide the public with quick, easy access to all New York City government services and information while Maintaining the highest possible level of customer service" (City of New York, 2010a).

The second case study is the E-government portal of the metropolitan region and Special Administrative Region of the People's Republic of China, Hong Kong. The approximately 7 million inhabitants make it one of the world's major metropolitan regions and one of the most important business and financial centres of Asia. In addition, Hong Kong has not only a major seaport, but also one of the largest airports in Asia and is one of the key hubs of international trade. Thus Hong Kong faced similar challenges as New York in the implementation of a local E-government portal.

Though it is a special administrative region with (largely) independent management, the portal of Hong Kong must nevertheless be integrated into the national E-government. Hong Kong began early in the development and implementation of user-oriented E-government services, one that integrated the various services of the different authorities (Hong Kong Special Administrative Region, 2010a). Since 2002, Hong Kong has followed with an E-business initiative that aims to establish a central E-government platform. This was realized in 2004 with the implementation of the E-government "Connectivity Platform" EGIS 


\section{Macrothink}

Journal of Public Administration and Governance

ISSN 2161-7104

2013, Vol. 3, No. 3

(E-government Infrastructure Service), under which the public information technology (IT) infrastructure of Hong Kong was centralized.

Because of its status as a special administrative zone, Hong Kong appears in both city as well in state rankings. Within this literature, many studies can be found that demonstrate the high standing of E-government in Hong Kong. Hong Kong was ranked by the World E-government Mayors Forum 2008 in second place among 86 cities in terms of "best practice E-government". In 2007, Hong Kong occupied second place in the "Digital Governance in Municipalities Worldwide Reports". Also the prestigious E-government ranking of WASEDA University has, since 2005, placed Hong Kong among the leading E-government states (Global Information and Telecommunication Institute, 2009). Figure 4 shows a section of the E-government portal of Hong Kong.

\section{Service specifications and requirements identified through}

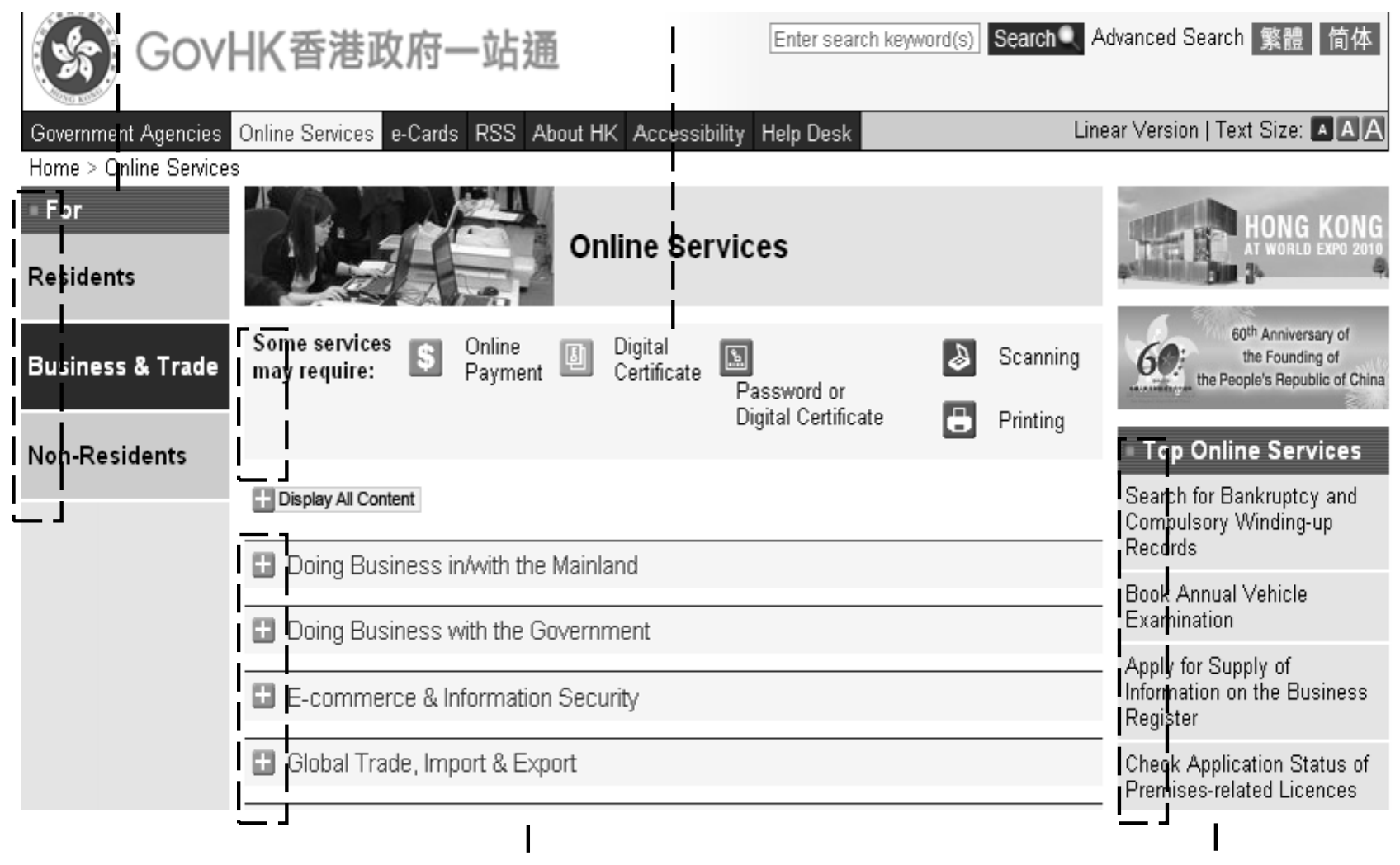

Online services in different categories

Figure 4: Sample of the E-government portal in Hong Kong (Hong Kong Special Administrative Region, 2010b).

The E-government portal is distinguished primarily by a clear structuring of the offered E-government Services. The services are sorted according to target groups and divided into numerous categories. Citizens are able in the "Residents" section to select local 


\section{Macrothink}

E-government services from eleven different categories. This clear-cut categorization provides a good overview of the entire range of services, which is why this study drew from the division of the GovHG portal. Regarding symbols, the user is already advised before selecting any service link of the requirements of use (e.g. password-protected login).

The third case study is the E-government portal of Singapore. While Hong Kong, as a Special Administrative Region of the People's Republic of China, is still a special case between municipal and national E-government, Singapore is a fully sovereign state. Nevertheless, with 4.8 million inhabitants in greater Singapore, the city-state has similar conditions as the two previous examples and is therefore also valid for the comparison of local E-government. Like Hong Kong, Singapore is a major hub of international trade and is the most important trading centre in Southeast Asia. In particular, the port of Singapore is one of the largest container ports in the world.

Second, due to its outstanding position in international E-government Singapore lends itself well to this comparative case study. In 2001, Singapore established the first "E-government Action Plan" (eGAP I), which already included a comprehensive strategy to expand E-government infrastructure and develop an E-government portal (Singapore Government, 2000). In 2004, the city-state increased its efforts once over with the second "E-government Action Plan" (eGAP II) (Singapore Government, 2010a). This provided for a radical IT-based administration and the development of a strong user-centric E-government portal. The implementation was so much woven into the administration that senior administrators and government officials as "eTown Mayor" bore directly responsibility for the various areas of development of E-government. As a result, Singapore has won numerous awards and their E-government is currently ranked among the top places in all international tables (Dutta and Mia, 2009; Economist Intelligence Unit, 2009). As in 2009, Singapore again in 2010 leads the WASEDA University "World E-government Ranking" (Global Information and Telecommunication Institute, 2009).

Singapore's prominent international position in E-government is reflected in the functionality and scope of their E-government portal. Besides the good structure and quick access to online payment services, the personal area of the portal is also notable. Similar to a privately-financed online portal, the E-government portal in Singapore has a log-in feature that allows the user into a personalized environment, from which the user can experience E-government services with a greater degree interactivity. In addition, the portal comes with modern Web 2.0 features and highly interactive applications such as online games for "game-based learning". Regarding service depth, all three cases are described in detail in the assessment. Figure 5 shows a section of the E-government portal of Singapore. 
Online services in different Online services for

different participants

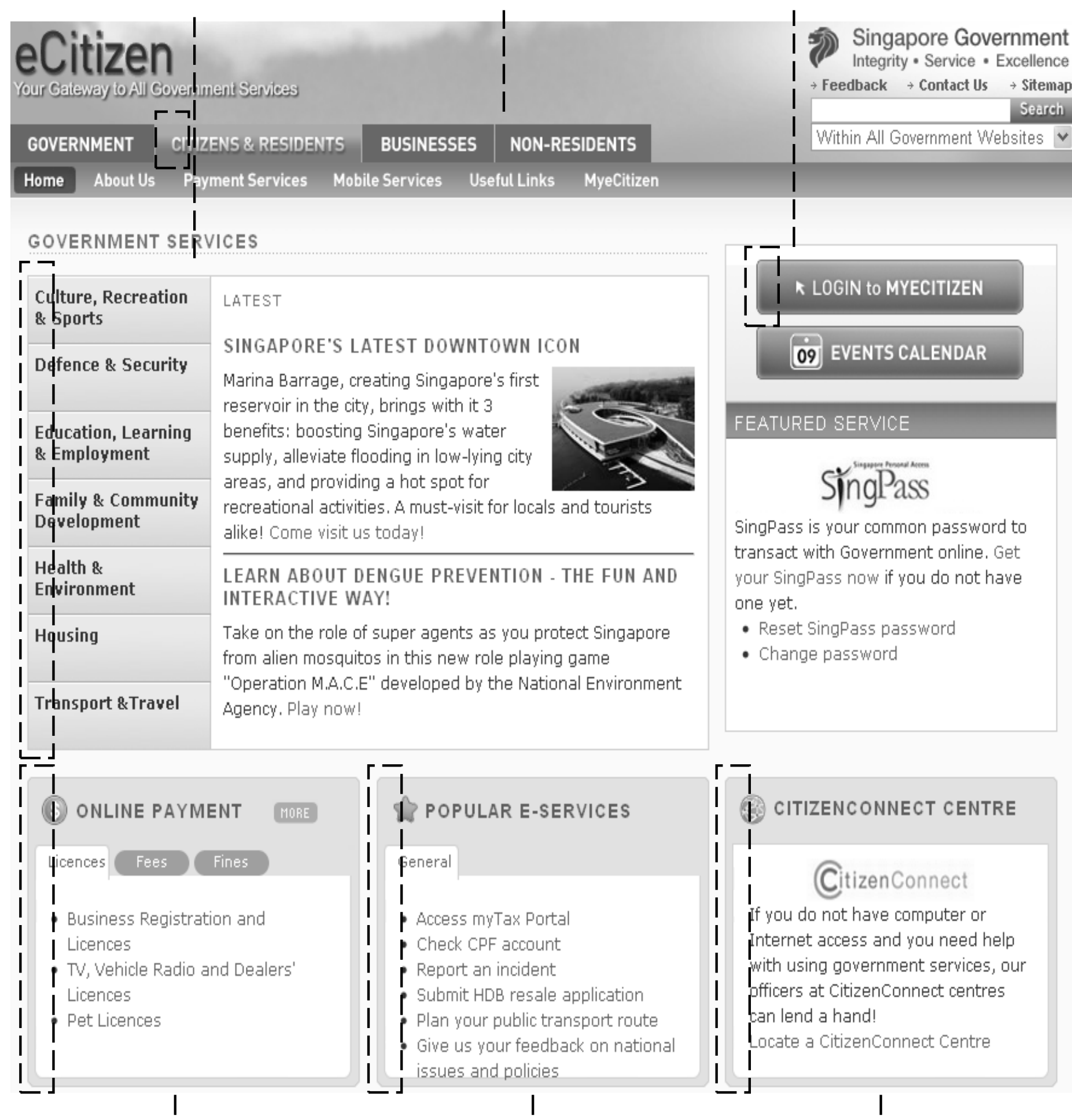

Figure 5: Sample of the E-government portal in Singapore (Singapore Government, 2010b). 


\subsection{Evaluation of the case study}

To begin the investigation of the case studies first an inventory of the number of available E-government Services was carried out. As described in section 2, this step evaluated how many different E-services the municipality provides to the citizens, which can be understood as the breadth of E-government services. Since the considered case studies offer a very large number of different services, these were categorized into eight clusters: education and employment (1), government agencies and the judiciary (2), health and environment (3), communication and technology (4), culture, sports and leisure (5), social and housing (6), transport and transport infrastructure (7) as well as economy and Finance (8). This division also helps to identify trends and development priorities in E-government services.

Table 2: Evaluation of Breadth of Service offers of E-government portals

\begin{tabular}{|c|c|c|c|c|}
\hline \multirow{2}{*}{$\begin{array}{l}\text { E-government } \\
\text { service categorie }\end{array}$} & \multirow{2}{*}{$\begin{array}{l}\text { E-government } \\
\text { service (examples) }\end{array}$} & \multicolumn{3}{|c|}{ Service quantity } \\
\hline & & $\begin{array}{l}\text { New York } \\
\text { City }\end{array}$ & $\begin{array}{l}\text { Hong } \\
\text { Kong }\end{array}$ & Singapore \\
\hline $\begin{array}{l}\text { education and } \\
\text { employment }\end{array}$ & $\begin{array}{l}\text { - Online procurement of publications } \\
\text { - School and university portals } \\
\text { - Local job portals (e.g. job search) }\end{array}$ & 17 & 18 & 36 \\
\hline $\begin{array}{l}\text { government agencies } \\
\text { and the judiciary }\end{array}$ & $\begin{array}{l}\text { - Complaint management } \\
\text { - E-voting } \\
\text { - Contact with emergency and security services }\end{array}$ & 44 & 16 & 47 \\
\hline $\begin{array}{l}\text { health and } \\
\text { environment }\end{array}$ & $\begin{array}{l}\text { - Environmental information (z.B. air quality data) } \\
\text { - Nutrition and medical information } \\
\text { - Hospital search, Medical service booking }\end{array}$ & 93 & 25 & 43 \\
\hline $\begin{array}{l}\text { communication and } \\
\text { technology }\end{array}$ & $\begin{array}{l}\text { - News services } \\
\text { - TV or Wi-Fi services }\end{array}$ & 6 & 6 & 17 \\
\hline $\begin{array}{l}\text { culture, sports and } \\
\text { leisure }\end{array}$ & $\begin{array}{l}\text { - Ticket and booking services } \\
\text { - Public library services (e. g. E-Mail reminder) }\end{array}$ & 27 & 21 & 14 \\
\hline social and housing & $\begin{array}{l}\text { - Online registration } \\
\text { - Online services for families } \\
\text { - Social housing disposability }\end{array}$ & 94 & 34 & 74 \\
\hline $\begin{array}{l}\text { transport and } \\
\text { transport } \\
\text { infrastructure }\end{array}$ & $\begin{array}{l}\text { - Traffic information services } \\
\text { - Online car registarion } \\
\text { - Online parking reservation }\end{array}$ & 62 & 22 & 50 \\
\hline \multirow[t]{2}{*}{$\begin{array}{l}\text { economy and } \\
\text { Finance }\end{array}$} & $\begin{array}{l}\text { - Online tax declaration } \\
\text { - Consumer information } \\
\text { - Online licensing and certificates }\end{array}$ & 39 & 12 & 25 \\
\hline & & 382 & 154 & 306 \\
\hline
\end{tabular}

Significant differences between the three case studies can already be seen regarding their range of service offerings. Several alternative approaches can be used in order to explain these differences. One explanation can provide by the differing styles for the organization of electronic government by the different cities. So, in New York one finds many divisions of services according to districts or responsibilities, resulting in an overall slightly higher granularity of services. This is particularly important for communication services, such as for complaints procedures. In contrast, in the case of Hong Kong there is a strong centralization 
of service offers (of the corresponding subportals), resulting in a lower total number of E-government services. The different political circumstances of each case can provide a further explanation for the differences in the service width of the case studies. Yet neither of these two explanations are sufficient to explain the full range of variation. Therefore, a closer look at the categories is required, from which the significant differences between and/or a high proportion of the total range of services can be explained.

Priorities in E-government services seem to be in the categories of (6) social and housing, and (3) health and the environment. The reason for this can be found in the composition of these categories. Both areas are characterized by a very large number of services in which the exchange of information between citizens and administration is paramount. These services can be more easily electronically mapped. In addition to many E-government services for the exchange of electronic documents (e.g. online reporting services), a large number of communication services (e.g. online appointments, forms to download) were also found. In all three observations the category of health and environment (3) is increasing in importance, out of which services in the field of environmental protection have an important part. All three municipalities report this service area as being a development priority.

Also of particular importance in all three case studies is the service area of transport and transport infrastructure (7). Among these are services both in the field of public transport as well as of individual and combined transportation infrastructure. This infrastructure in metropolitan areas, as in the three case studies, traditionally has a special importance due to high traffic volumes. In addition, all three cities have major airports and seaports, as well as a very complex infrastructure. In both Hong Kong and New York there are many bridges (including some toll) and ferry services which have a web presence (e.g. online ticket purchase, complaint forms).

In contrast, regarding education and employment (1), government and judiciary (2), culture, sport and leisure (5) and economic and financial services (8), the portals have a rather average breadth. In addition, the case studies show that in these categories New York and Singapore have many similar services. Hong Kong alone offers a lower number of services. One also observes in the case of New York that in the category of education and employment (1) there are a relatively lower number of E-government services in comparison to other services offered.

With relatively few services in all three observations presented, only the services for communications and technology (4) are developed below average. The cases of New York and Hong Kong offer first of all services sector for the local media (City TV, radio) and only a few mobile E-government services. In contrast, Singapore has a large number of mobile services that are assigned to communications and technology (4). However, it can be assumed that the other cases will follow the example of Singapore and also implement more mobile services in their E-government portals.

In summary, it can be stated that in spite of their differences all three selected E-government portals are distinguished by a great breadth of services offered. They therefore meet criteria of what we would expect for top portals. Especially the city of New York has managed to create a citizen portal, through which a very large number of E-government services are centrally available. Over all instances it can be stated that a high importance was given to 
social and housing (6) and health and the environment (3). Especially in the medical field all three cities have an above average number of E-government services. From this the special relevance of e-health in advanced E-government can be seen (Wirtz, 2010). Another trend are services relating to social housing and urban residential space planning. Here again, all three case studies exhibit many services.

The qualitative analysis of E-government services in New York, Hong Kong and Singapore will be aided through the use of the E-government maturity levels. These can be divided into those services not fully available online (information and communication) and those which are fully available (transaction, participation and integration) online (see 2.2). It should be noted that not all services can fully reproduced online, making a level of fully online level practically unattainable. An example of such a service could be a request for the repair of a pothole. For this obviously only the communication component can occur online. The following Table 3 shows the evaluation of three cases based on the share of fully online services in a service category of the portal.

Table 3: Evaluation of E-government development

\begin{tabular}{|c|c|c|c|c|}
\hline \multirow{2}{*}{$\begin{array}{l}\text { E-government } \\
\text { service categorie }\end{array}$} & \multirow{2}{*}{$\begin{array}{l}\text { E-government } \\
\text { service (examples) }\end{array}$} & \multicolumn{3}{|c|}{ Full online availability } \\
\hline & & $\begin{array}{l}\text { New York } \\
\text { City }\end{array}$ & $\begin{array}{l}\text { Hong } \\
\text { Kong }\end{array}$ & Singapore \\
\hline $\begin{array}{l}\text { education and } \\
\text { employment }\end{array}$ & $\begin{array}{l}\text { - Online procurement of publications } \\
\text { - School and university portals } \\
\text { - Local job portals (e.g. job search) }\end{array}$ & 1 & 2 & 3 \\
\hline $\begin{array}{l}\text { government agencies } \\
\text { and the judiciary }\end{array}$ & $\begin{array}{l}\text { - Complaint management } \\
\text { - E-voting } \\
\text { - Contact with emergency and security services }\end{array}$ & 2 & 2 & 3 \\
\hline $\begin{array}{l}\text { health and } \\
\text { environment }\end{array}$ & $\begin{array}{l}\text { - Environmental information (z.B. air quality data) } \\
\text { - Nutrition and medical information } \\
\text { - Hospital search, Medical service booking }\end{array}$ & 0 & 1 & 3 \\
\hline $\begin{array}{l}\text { communication and } \\
\text { technology }\end{array}$ & $\begin{array}{l}\text { - News services } \\
\text { - TV or Wi-Fi services }\end{array}$ & 1 & 2 & 4 \\
\hline $\begin{array}{l}\text { culture, sports and } \\
\text { leisure }\end{array}$ & $\begin{array}{l}\text { - Ticket and booking services } \\
\text { - Public library services (e. g. E-Mail reminder) }\end{array}$ & 3 & 2 & 3 \\
\hline social and housing & $\begin{array}{l}\text { - Online registration } \\
\text { - Online services for families } \\
\text { - Social housing disposability }\end{array}$ & 2 & 2 & 3 \\
\hline $\begin{array}{l}\text { transport and } \\
\text { transport } \\
\text { infrastructure }\end{array}$ & $\begin{array}{l}\text { - Traffic information services } \\
\text { - Online car registarion } \\
\text { - Online parking reservation }\end{array}$ & 1 & 2 & 2 \\
\hline \multirow[t]{2}{*}{$\begin{array}{l}\text { economy and } \\
\text { Finance }\end{array}$} & $\begin{array}{l}\text { - Online tax declaration } \\
\text { - Consumer information } \\
\text { - Online licensing and certificates }\end{array}$ & 2 & 3 & 4 \\
\hline & & 2 & 2 & 3 \\
\hline $\begin{array}{ll}0 & \begin{array}{l}\text { No/marginal full } \\
\text { online availability }\end{array}\end{array}$ & $1 \begin{array}{l}\text { Few fullonline } \\
\text { services }\end{array} \quad 2 \begin{array}{l}\text { Medium ratio of } \\
\text { full online } \\
\text { services }\end{array}$ & $\begin{array}{l}\text { High ratio of full } \\
\text { online services }\end{array}$ & $\begin{array}{l}\text { Ver } \\
\text { full } \\
\text { sen }\end{array}$ & $\begin{array}{l}\text { gh ratio of } \\
\text { ne }\end{array}$ \\
\hline
\end{tabular}

Again, the selected case studies are at a very high level of development. All three 
E-government portals have at least an average number of fully online services, which when considering the number of services that cannot be developed fully online is already an excellent achievement. While New York has a lower proportion of fully online services, though it has a close to an average depth of service, the ratio of fully online services to services that are only partially available online is nearly balanced in the case of Hong Kong. Singapore has an average high to very high proportion of fully online services, well ahead of Hong Kong.

On the whole, especially strongly development has occurred in the areas of economics and finance (8), culture, sports and leisure (5). Regarding the economic and financial (8) area it is important to note that the services offered are primarily licensing and payment services. These can be successful through the use of modern information technology, such as implementing the verification and encryption procedures and standards required for effective E-government (the legal framework required). In the field of culture, sport and recreation (5) make up a large share of the highly developed services, especially such services as public libraries as well as ticketing and reservation services (e.g. for sports facilities). These can be conducted completely online, since virtual goods are exchanged (Wirtz, 2010). In the case of New York the category of cultural, sporting and leisure (5) is developed far above average when compared to other areas. This is one of the E-government development priorities for the City of New York, due mainly to the very wide range of cultural offers (in comparison to the other cases).

Considering all of the cases, average E-government development was exhibited in the areas of education and employment (1), government and legal process (2), communication and technology (4) and social affairs and housing (6). The three case studies showed a very similar service depth in the categories of authorities and jurisdictions and Social Affairs and Housing. It seems likely that in these areas, ways in which to implement fully online services have been largely exhausted. The very high proportion of fully online services for the field of communications and technology (4) in Singapore is due to the supply of mobile services.

The categories of traffic and transport infrastructure (7) and health and the environment (3) are, however, developed below average in all cases examined here. Although in both these areas there are some outstanding and highly interactive services at the developmental level of participation, the potential for a higher proportion of fully online services is limited. This is mainly due to the very high share of services at the communication level of development. Many of these services are not able to attain a higher level of development due to the necessity of physical delivery. In particular, New York is distinguished by a very large proportion of communication services in these two categories. These include, above all, various complaints/appeals services and a comprehensive suggestion system.

Singapore has a high proportion of fully online services in all categories. Especially in the category of communications and technology (4), their E-government offers a variety of mobile fully online Services. With regard to the depth of the service, Singapore's leading position in E-government extends from the national level down to the local level as well. This is not surprising since, as a city-state, in Singapore the overall E-government efforts can be concentrated and municipal and national portal are united. It is clear that the legal and administrative organizational framework represents a potential limiting or reinforcing factor 


\section{Ml Macrothink}

Journal of Public Administration and Governance

ISSN 2161-7104

2013, Vol. 3, No. 3

for the online service level of E-government portal.

Overall the results from the data analysis show that while there are international leaders in E-government there are still considerable differences in the development of E-government services offered. In particular, in all cases the category business and finance (8) offers a very high proportion of fully online services. This analysis clearly shows which high level services (especially those related to fees, taxes and licenses) have the potentials to be completely transferred to the local E-government portal. The areas of authority and jurisdiction (2), communication and technology (4) and social affairs and housing (6) also exhibited development potential with regard to their attainable level of E-government development. Here, Singapore can serve as a benchmark for E-government implementation.

\subsection{Innovative E-government services and communication services}

Both Singapore and New York and Hong Kong are characterized by highly innovative E-government services. Among them are some services that have a highly participatory and inclusive character. On the basis of three selected services and/or subportals this shall be illustrated further and important trends are identified and highlighted. In addition, the case studies will be compared in terms of their use of modern forms of online communications.

A remarkable online service provided by the City of New York through the portal "NYC Service" since April 2009 is a subportal for offers of, searches for and placement in volunteer work (City of New York, 2010c). The E-government portal gives citizens the opportunity to actively participate in E-government and should therefore be described as participatory. As several agencies and organizations cooperate on the portal, it is also an integrated service. Today there are already 60 public and nonprofit organizations participating in the initiative and which through the service portal assign a large number of voluntary tasks to volunteers. Figure 6 shows a section of the portal "NYC Service".

NYC service on facebook and RSS feed

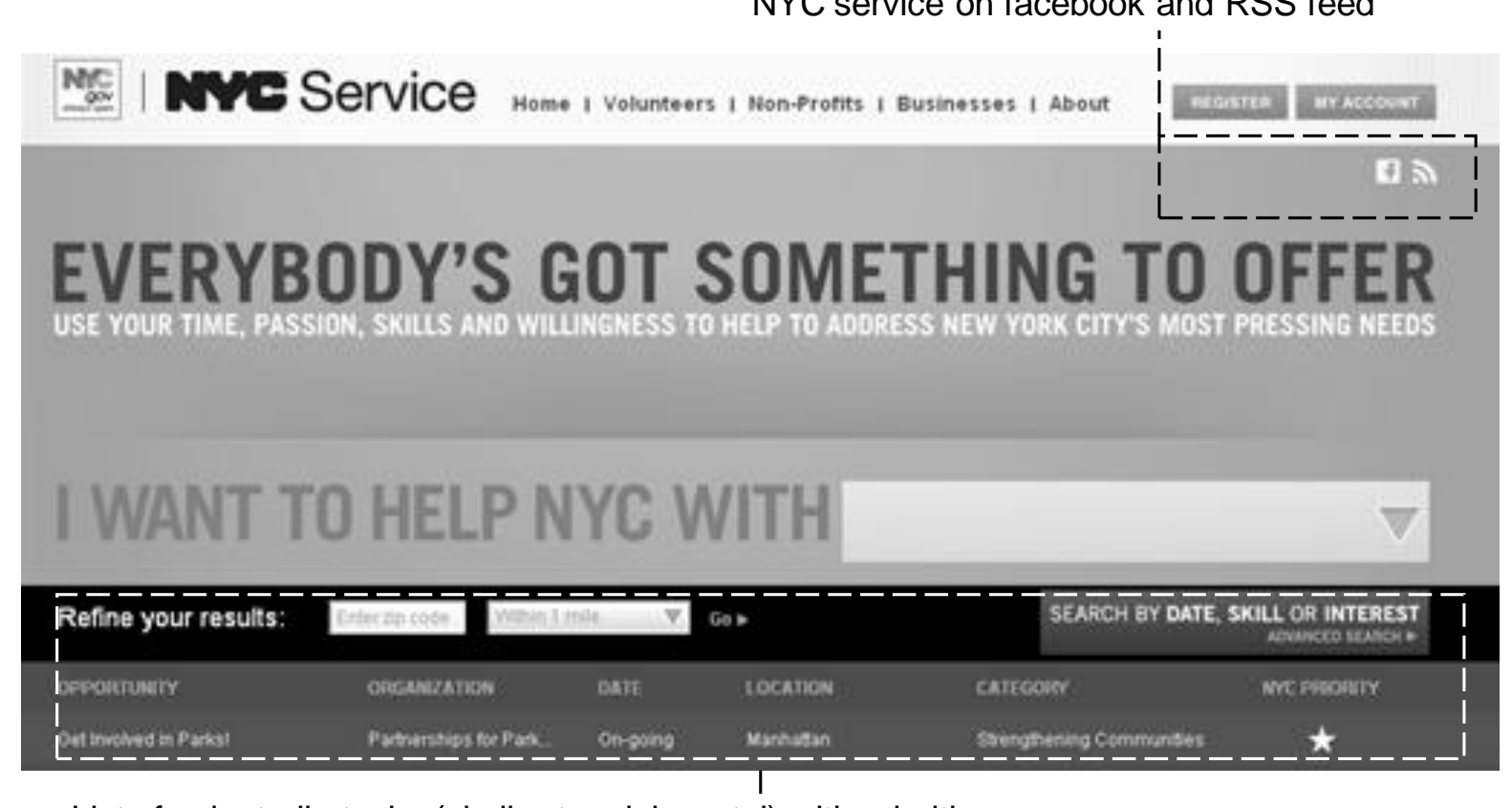

List of voluntarily tasks (similar to a job portal) with priorities

Figure 6: Portal for voluntary activities of the City of New York (City of New York, 2010c). 
Hong Kong also has a variety of innovative E-government services. Selected here is the Service Portal of the Environmental Protection Department of Hong Kong, shown in Figure 7, on which citizens can place classifieds ads or donate everyday items to charity. This is an adaptation of the well known and widely used platform for classified ads in e-business, the functions of which have been adopted and integrated into the architecture of an E-government portal. The portal serves no revenue generating purpose and instead aims, according to the Department, to: "to Facilitate the exchange of unwanted but still usable items to help reduce, reuse and recycle waste in Hong Kong (Enviromental Protection Department Hong Kong, 2010)."

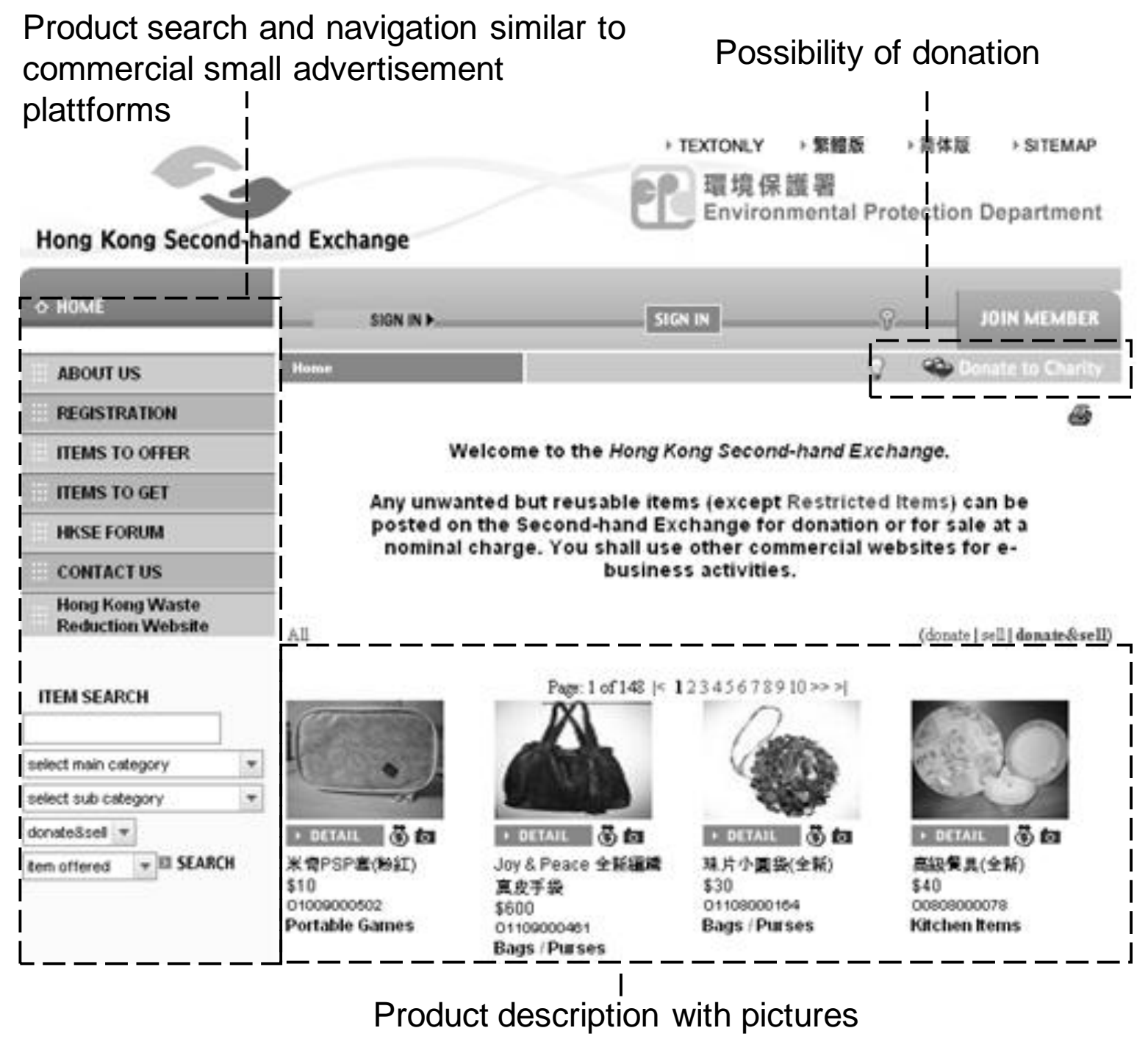

Figure 7: Classified Ads platform of the Environmental Agency of Hong Kong (Enviromental Protection Department Hong Kong, 2010)

Mobile applications are currently becoming increasing more significant for E-government. In 


\section{Macrothink}

Journal of Public Administration and Governance

ISSN 2161-7104

2013, Vol. 3, No. 3

the area of mobilE-government Singapore has introduced, among other things, the pioneering portal "MyeCitizen". In addition to services such as communicating via SMS (e.g. as a reminder to submit one's tax return), Singapore users have available to them a mobile service platform called "MESH" (Mobile eService Hub). Through this platform, users can access various E-government services on demand through their mobile device (NCS Group, 2010). Available services include everything from access to traffic and weather information up to the ability for members of the national security authorities to apply for travel permits. Figure 8 shows the use of "MESH" on a mobile device.

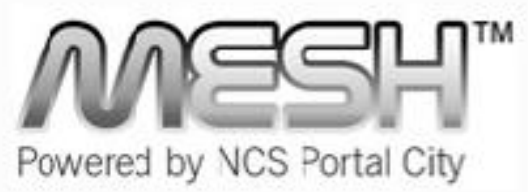

MeSH $^{\text {m }}$ (Mobile eServices Hub) is the one-stop mobile service platform suite offering government eServices and value-added lifestyle promotions and contents to all mobile users.

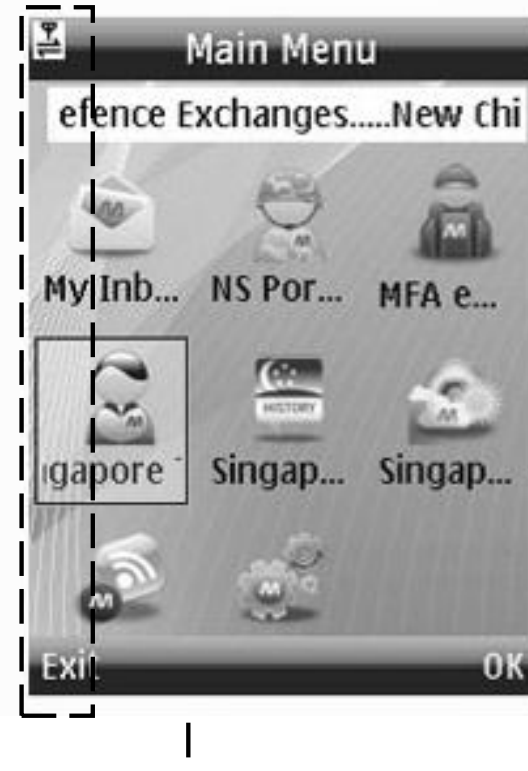

Main menu of the mobile service

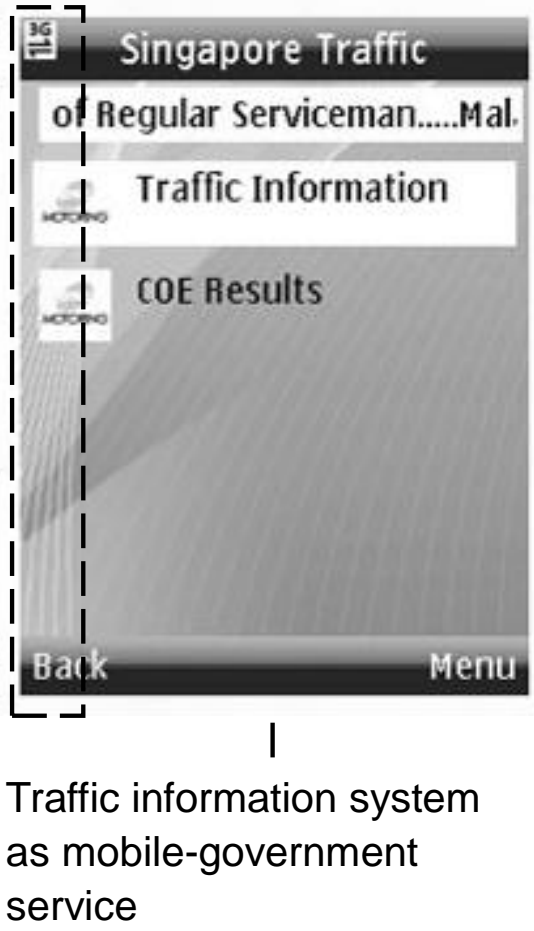

Figure 8 Mobile Service Suite MESH (NCS Group, 2010)

Also of great importance for the connectivity of a modern E-government portal is the use of modern forms of communication (Digital Communities Magazine, 2010). This would prove especially helpful if the community wants to connect with or facilitate contact with/between younger people. Modern (Web 2.0) forms of communication that can also be found in E-government applications include blogs, Twitter and RSS feeds, as well as social networks (including Facebook and MySpace) and webcasts (video / audio podcasts) offered as 


\section{Macrothink}

Journal of Public Administration and Governance

ISSN 2161-7104

2013, Vol. 3, No. 3

downloads or on its own YouTube channel. In addition, by means of linking (Mash-Ups) to content-sharing services such as Digg, StumbleUpon or Xanga, citizens have the opportunity to share web content displayed on the E-government portals with other users (Wirtz, 2010). Table 4 shows a comparison of the cases regarding their implementation of modern online communication services.

Table 4: Use of modern communications services in the cases examined

\begin{tabular}{|c|c|c|c|}
\hline Communication services & New York & Hong Kong & Singapore \\
\hline Blogs & $\checkmark$ & $\checkmark$ & $\checkmark$ \\
\hline Dynamic Contact Forms & $\checkmark$ & $\checkmark$ & $\checkmark$ \\
\hline $\begin{array}{l}\text { Sharing } \quad \text { services } \\
\text { integration }\end{array}$ & $\checkmark$ & $\checkmark$ & $\checkmark$ \\
\hline RSS-Feeds & $\checkmark$ & $\checkmark$ & $\checkmark$ \\
\hline $\begin{array}{l}\text { Social networks/ } \\
\text { community plattforms }\end{array}$ & $\begin{array}{l}\text { Facebook, } \\
\text { Myspace, } \\
\text { Flickr }\end{array}$ & Facebook & Facebook \\
\hline Twitter & $\checkmark$ & $\checkmark$ & $\checkmark$ \\
\hline $\begin{array}{l}\text { Webcasts } \\
\text { (Video-/audiocasts) }\end{array}$ & $\begin{array}{l}\text { Youtube, } \\
\text { Download }\end{array}$ & $\begin{array}{l}\text { Download, } \\
\text { (Youtube) }\end{array}$ & $\begin{array}{l}\text { Youtube, } \\
\text { Download }\end{array}$ \\
\hline
\end{tabular}

The three case studies considered here use the full range of modern online communications methods. Both New York and Hong Kong and Singapore also have blogs, Dynamic Contact Forms, a connection to sharing services, RSS feeds and Twitter. These communication services are an important part of a modern municipal E-government platform and might be considered obligatory components for any high quality portal such as those chosen for this study. Differences between the portals in this dimension are thus only in relation to their usage of social networks and/or Webcasts. While New York City has its own account on 
Facebook, Myspace and Flickr, Hong Kong and Singapore concentrate their engagement on the world's most popular social network, e.g. Facebook. Therefore, regarding the usage of modern (Web 2.0) communications, New York is regarded as the leader.

E-government raises questions, in particular in the context of E-participation and Web 2.0, regarding democratic theory and privacy. Especially in light of the democratic theory of the modern E-government services it is evident that E-government poses risks in some contexts. Through the use of the Web some individual citizens or groups may be excluded from the use of certain services (Helbig et al., 2009). The development and use of innovative E-government services risks exacerbating the unequal treatment of citizens without versus those with access to the Web (Nelson, 2002; Robinson, 2003).

Access to the Internet can become a critical factor in determining whether a citizen can use an E-government service or participate in an electronic democratic process. This phenomenon is described by the so-called Digital Divide. In this context, socio-demographic characteristics such as age, ethnicity or educational levels, but also geographic factors, can play an important role (Helbig et al., 2009).

The Digital Divide is considered especially critical in connection with E-services, as analyses have shown that many such E-services have no offline equivalent, but were directly derived from and developed for Web 2.0. This fact is particularly evident at the highest stage of development services: e-participation. The digital divide has expanded in this context, most of all due to the increased use of Web 2.0 tools. Many of these tools require a separate application (e.g. a Facebook account) and require a certain routine use that inexperienced (especially older) Web users often do not have. In addition, many Web 2.0 tools still have barriers to participation. Thus even users who have access to the Internet may be excluded from participation by these additional hurdles.

Often the use of modern Web 2.0 tools is closely connected to the goal of implementing simpler participation procedures. In this context, the use of participatory e-services offers opportunities to promote democracy. Population groups that do not yet benefit from certain government services or that could not (e.g. due to geographic distances) or did not want to (e.g. due to a lack of interest in classical democratic process) participate in democratic processes can become more involved with the help of the Web. Balancing the opportunities and risks of Web 2.0 therefore represents one of the main tasks of e-service implementation. The implementation decision is strongly dependent on the specific e-service.

A second important question in this context is how to ensure the privacy of citizens and the protection of their personal data. Here, modern e-government services and their portals have often come under fire, and given their ability to collect a large amount of user data and possible use it for other purposes, their e-government Privacy Policy plays a prominent role (Henriksson et al., 2007; Dawes, 2009). However, since these issues have to be considered largely in the context of local laws and regulations on data protection, this point can be only briefly considered here. However, with the use of Web 2.0 tools these problems could increase significantly. In addition to the Government, also private providers of certain Web 2.0 services and their own privacy policy play an important role. Given these issues, the use 
of Web 2.0 tools has to be considered very carefully.

\section{Conclusion}

The investigation of these three leading international and award winning E-government portals has shown the high degree of development that the municipal E-government has now reached at the international level. All the cases considered offer their citizens a variety of sophisticated E-government services. In this study, the cities of New York, Hong Kong and Singapore were presented as leaders in innovation which show the possibilities of modern E-government with the implementation of Web 2.0 functionality and other modern forms of communication. But we can identify some implementation differences between the portals in terms of the depth and breadth of the services offered. In particular, the analysis has shown that the different service areas in E-government are developing to varying degrees.

With respect to the breadth of service, two especially important service categories can be identified. The areas of social affairs and housing, and health and environment exhibited great service breadth in all the cases examined. Of utmost importance are services in e-health. A trend which is evident in all cases is a high concentration on services in the field of environment and nature conservation. The examined local authorities are limited not only to the provision of urban environmental data (which were not evaluated in this analysis) but also offer interactive E-government services. The high breadth of service for transportation and transportation infrastructure matches the expectation that metropolitan areas with internationally important transport hubs would promote this area.

With regard to the depth of service it had to be noted that the development of a high-level of fully online services has natural limitations, since many services have an essential physical component. These areas are primarily health and the environment and traffic and transport infrastructure. However, in the areas where the achievement of a high proportion of fully online services is possible, the case studies show some very large service depth. Particularly noteworthy is the category business and finance. In addition, the field of culture, sports and leisure (especially in the case of New York) is developed above average. High development potential can be seen also for the areas of jurisdiction and authority as well as communication and technology. Nevertheless, in all areas Singapore has most developed depth of service and must therefore be regarded as a benchmark for the implementation of E-government services.

The study, however, has some limitations. Firstly, the use of e-government development stages as a key evaluation criterion it is not without controversary in the literature. Although they are widely used in the e-government research, they represent a relatively rigid system and may over-emphasize the technological component of service development. A comparative study - for example by means of an additional survey - could help verify the results of this investigation.

Another limitation may relate to the selection and number of case studies. Although the selection was made based on many international benchmarks, there are other communities that also hold a leading position in e-government. A study of these communities would also be of great interest. Many other interesting aspects of e-services also arose in the course of this study but which either were not or only briefly addressed. In particular, questions of 
democratic theory are important and require a more thorough examination. Therefore, the results can be used for further theoretical and empirical research. Its components and structure can be regarded as a foundation for other studies that focus on e-government.In general, future research that focuses on the examination of innovative e-government services and their compatibility with democratic theory is highly recommended.

All together, a clear trend towards interactive and participatory local E-government services can be seen from the analysis of the data and the selected service examples. In addition, the linking of advanced communications services and community platforms is essential. The three selected case studies demonstrate this clearly and their high service levels provide an example for best-practice analysis or for the benchmarking of municipal E-government portals.

\section{References}

Alanezi, M.A., Kamil, A. and Basri, S. (2010), A proposed instrument dimensions for measuring e-government service quality. International Journal of u- and e- Service, Science and Technology, 3(4), 1-18.

Al-Haddad, S.A., Hyland, P. and Hubona, G. (2011), An Assessment Tool for E-Government System Performance:-A Citizen-Centric Model. Paper 181, in AIS (Ed.), Proceedings of the Seventeenth Americas Conference on Information Systems, AIS, Detroit, 1-11.

Alsaghier, H., Ford, M., Nguyen, A. and Hexel, R. (2009), “Conceptualising Citizen's Trust in e-Government: Application of Q Methodology.”, Electronic Journal of e-Government, 7(4), 295-310.

Al-Sobhi, F., Weerakkody, V. and El-Haddadeh, R. (2011), The Relative Importance of Intermediaries in eGovernment Adoption: A Study of Saudi Arabia. In Janssen, M., Scholl, H.J., Wimmer, M.A. and Tan, Y.-h. (Eds.), Electronic Government. 10th IFIP WG 8.5 International Conference. EGOV 2011. Delft, The Netherlands, August/September 2011. Proceedings (pp. 62-74). Springer Berlin Heidelberg, Berlin,

Andersen, K.V. and Henriksen, H.Z. (2006), "E-government maturity models: Extension of the Layne and Lee model", Government Information Quarterly, Vol. 23 No. 2, pp. 236-248.

Arduini, D., Zanfei, A., Denni, M. and Giungato, G. (2011), The eGovernment Services Delivery of the Italian Municipalities. In Janssen, M., Scholl, H.J., Wimmer, M.A. and Tan, Y.-h. (Eds.), Electronic Government. 10th IFIP WG 8.5 International Conference. EGOV 2011. Delft, The Netherlands, August/September 2011. Proceedings (pp. 144-158), Springer Berlin Heidelberg, Berlin,

Baum, C. and DiMaio, A. (2000), Gartner's Four Phases of E-Government Model, available at: http://www.gartner.com/DisplayDocument?id=317292 (accessed October 30, 2011).

Chen, C.-W. (2010), Impact of quality antecedents on taxpayer satisfaction with online tax-filing systems-An empirical study, Information \& Management, 47 5(6), 308-315.

Chutimaskul, W., Funilkul, S. and Chongsuphajaisiddhi, V. (2008), The quality framework of e-government development. In Janowski, T. and Pardo, T.A. (Eds.), Proceedings of the 2nd 
International Conference on Theory and Practice of Electronic Governance - ICEGOV '08 (pp. 105-109), ACM Press, Kairo,

Coursey, D. and Norris, D.F. (2008), Models of E-Government: Are They Correct? An Empirical Assessment. Public Administration Review, 68(3), 523-536.

Dawes, S.S. (2008), An Exploratory Framework for Future E-Government Research Investments. In IEEE (Ed.), Proceedings of the 41st Annual Hawaii International Conference on System Sciences (p. 201). IEEE,

Dawes, S.S. (2009), Governance in the digital age: A research and action framework for an uncertain future. Government Information Quarterly, 26(2), 257-264.

Delitheou, V. and Maraki, M. (2010), Research into citizens' attitude towards electronic municipal services (e-local government). Journal of Public Administration and Policy Research, 2(3), 39-45.

Deng, H. (2008), Towards objective benchmarking of electronic government: an inter-country analysis. Transforming Government: People, Process and Policy, 2(3), 162-176.

Esteves, R. and Joseph, R. (2008), A comprehensive framework for the assessment of eGovernment projects. Government Information Quarterly, 25(1), 118-132.

Evans, D.Y.D. (2005), E-government: An analysis for implementation: Framework for understanding cultural and social impact. Government Information Quarterly, 22(3) 354-373.

Gilbert, D., Balestrini, P. and Littleboy, D. (2004), Barriers and benefits in the adoption of e-government. International Journal of Public Sector Management, 17(4), 286-301.

Grönlund, Å. (2011), Connecting eGovernment to Real Government - The Failure of the UN eParticipation Index. In Janssen, M., Scholl, H.J., Wimmer, M.A. and Tan, Y.-h. (Eds.), Electronic Government. 10th IFIP WG 8.5 International Conference. EGOV 2011. Delft, The Netherlands, August/September 2011. Proceedings (pp. 26-37). Springer Berlin Heidelberg, Berlin,

Halaris, C., Magoutas, B., Papadomichelaki, X. and Mentzas, G. (2007), Classification and synthesis of quality approaches in e-government services. Internet Research, 17(4), 378-401.

Heeks, R. (2008), Benchmarking e-government: Improving the national and international measurement evaluation and comparison of e-government. In Irani, Z. and Love, P.E.D. (Eds.), Evaluating information systems: Public and private sector (pp. 257-301). Elsevier/Butterworth-Heinemann, Amsterdam; London,

Helbig, N., Gil Garci, J.R. and Ferro, E. (2009), Understanding the complexity of electronic government: Implications from the digital divide literature. Government Information Quarterly, 26(1), 89-97.

Henriksson, A., Yi, o., Frost, B. and Middleton, M. (2007), Evaluation instrument for e-government websites. Electronic Government, an International Journal, 4(2), p. 204.

Hiller, J.S. and Bélanger, F. (2001), Privacy Strategies for Electronic Government, IBM Center for the Business of Government, Washington, DC. 


\section{Al Macrothink}

Journal of Public Administration and Governance ISSN 2161-7104 2013, Vol. 3, No. 3

Irani, Z., Love, P.E. and Jones, S. (2008), Learning lessons from evaluating eGovernment: Reflective case experiences that support transformational government. The Journal of Strategic Information Systems, 17(2), 155-164.

Jansen, J., Vries, S. de and van Schaik, P. (2010), The Contextual Benchmark Method: Benchmarking e-Government services. Government Information Quarterly, 27(3), 213-219.

Kaisara, G. and Pather, S. (2011), The e-Government evaluation challenge: A South African Batho Pele-aligned service quality approach. Government Information Quarterly, 28(2), 211-221.

Karunasena, K. and Deng, H. (2012), Critical factors for evaluating the public value of e-government in Sri Lanka. Government Information Quarterly, 29(1), 76-84.

Kaylor, C., Deshazo, R. and van Eck, D. (2001), Gauging e-government: A report on implementing services among American cities. Government Information Quarterly, 18(4), 293-307.

Khan, G.F., Moon, J., Zo, H. and Rho, J.J. (2010), Civil Conflict,Digital Divide,and E-government Service Adoption: A Conflict Theory Approach, Paris.

Layne, K. and Lee, J. (2001), Developing fully functional E-government: A four stage model, Government Information Quarterly, 18(2), 122-136.

Lee, J. (2010), "10 year retrospect on stage models of e-Government: A qualitative meta-synthesis”, Government Information Quarterly, 27(3), 220-230.

Magoutas, B. and Mentzas, G. (2010), SALT: A semantic adaptive framework for monitoring citizen satisfaction from e-government services. Expert Systems with Applications, 37(6), 4292-4300.

McHenry, W. and Borisov, A. (2006), Measuring E-Government: A Case Study Using Russia. Communications of the Association for Information Systems No. 17, 905-940.

Moon, M.J. (2002), The Evolution of E-Government among Municipalities: Rhetoric or Reality? Public Administration Review, 62(4), 424-433.

Nelson, L. (2002), Protecting the common good. Technology, objectivity, and privacy. Public Administration Review No. 62, 69-73.

Norris, D.F. and Lloyd, B.A. (2006), The Scholarly Literature on E-Government: Characterizing a Nascent Field. International Journal of Electronic Government Research, . 2(4), 40-56.

OECD (2003), The Case for e-government Excerpts from the OECD Report "the e-government Imperative". OECD Journal on Budgeting, 3(1), 61-96.

Pazalos, K., Loukis, E. and Nikolopoulos, V. (2012), A structured methodology for assessing and improving e-services in digital cities. Telematics and Informatics, 29(1), 123-136.

Reddick, C.G. (2004), Empirical Models of E-Government Growth in Local Governments. e-Service Journal, 3(2), 59-84. 
Robinson, J.D.P.\&.H.E. (2003), New Social Survey Perspectives on the Digital Divide. IT \& Society, 1(5), 1-22.

Rotchanakitumnuai, S. (2008), Measuring e-government service value with the E-GOVSQUAL-RISK model”, Business Process Management Journal. 14(5), 724-737.

Rowley, J. (2011), e-Government stakeholders-Who are they and what do they want? International Journal of Information Management, 31(1), 53-62.

Roy, J. (2006), E-Government and Local Governance in Canada: An Examination of Front Line Challenges and Federal Tension. Public Administration and Management, 11(4), 306-350.

Sigala, M. (2009), E-service quality and Web 2.0: expanding quality models to include customer participation and inter-customer support. The Service Industries J. The Service Industries Journal, 29(10), 1341-1358.

Stowers, G. (2004), Issues in e-commerce and e-government service delivery. In Pavlichev, A. and Garson, G.D. (Eds.), Digital government: Principles and best practices (pp. 169-185). Idea Group Pub., Hershey,

Sumak, B.P.G.H.M. (2009), Towards an e-service knowledge system for improving the quality and adoption of e-services. Proceedings of the 22nd Bled eConference 'eEnablement: Facilitating an Open, Effective and Representative Society', Paper 4.

Sung, Y.H., Liu, S.H., Liao, H.L. and Liu, C.M. (2009), Service Quality between e-Government Users and Administrators. I Ways Journal of E-Government Policy and Regulation, 32(4), 241-248.

Tan, F.B. and Chou, J.P.C. (2008), The Relationship Between Mobile Service Quality, Perceived Technology Compatibility, and Users' Perceived Playfulness in the Context of Mobile Information and Entertainment Services. International Journal of Human Computer Interaction, 24(7), 649-671.

Thompson, D.V., Rust, R.T. and Rhoda, J. (2005), The business value of e-government for small firms. International Journal of Service Industry Management, 16(4), 385-407.

United Nations (2003), World public sector report 2003: E-government at the crossroads. United Nations, Dept. of Economic and Social Affairs, New York.

UNPAN (2002), Benchmarking E-government a global perspective. Assessing the progress of the member states. available at: http://www.unpan.org/e-government/Benchmarking\%20E-gov\%202001.pdf.

UNPAN (2008), United Nations e-Government Survey 2008. From e-Government to Connected Governance. available at: http://unpan1.un.org/intradoc/groups/public/documents/un/unpan028607.pdf.

Verdegem, P. and Verleye, G. (2009), User-centered E-Government in practice: A comprehensive model for measuring user satisfaction. Government Information Quarterly, 26(3), 487-497. 
Wang, L., Bretschneider, S. and Gant, J. (2005), Evaluating Web-Based E-Government Services with a Citizen-Centric Approach. In IEEE (Ed.), Proceedings of the 38th Annual Hawaii International Conference on System Sciences (pp. 1-10). IEEE, Washington,

Wescott, C. (2001), E-Government in the Asia-pacific region. Asian Journal of Political Science, 9(2), 1-24.

Wirtz, B.W., Mory, L. and Ullrich, S. (2011), eHealth in the public sector - An empirical analysis of the acceptance of Germany's electronic health card. Public Administration, 90(3), 642-663.

Wolfinbarger, M. and Gilly, M.C. (2003), eTailQ: dimensionalizing, measuring and predicting etail quality. Journal of Retailing, 79(3), 183-198.

\section{Copyright Disclaimer}

Copyright reserved by the author(s).

This article is an open-access article distributed under the terms and conditions of the Creative Commons Attribution license (http://creativecommons.org/licenses/by/3.0/). 